\title{
圈/ QUEEN'S UNIVERSITY BELFAST

\section{Extracorporeal carbon dioxide removal for lowering the risk of mechanical ventilation: research questions and clinical potential for the future}

International ECMO Network (ECMONet) (2018). Extracorporeal carbon dioxide removal for lowering the risk of mechanical ventilation: research questions and clinical potential for the future. The Lancet Respiratory Medicine, 6(11), 874-884. https://doi.org/10.1016/S2213-2600(18)30326-6

\section{Published in:}

The Lancet Respiratory Medicine

\section{Document Version:}

Peer reviewed version

Queen's University Belfast - Research Portal:

Link to publication record in Queen's University Belfast Research Portal

\section{Publisher rights}

Copyright 2018 Elsevier Ltd.

This manuscript is distributed under a Creative Commons Attribution-NonCommercial-NoDerivs License

(https://creativecommons.org/licenses/by-nc-nd/4.0/), which permits distribution and reproduction for non-commercial purposes, provided the author and source are cited.

\section{General rights}

Copyright for the publications made accessible via the Queen's University Belfast Research Portal is retained by the author(s) and / or other copyright owners and it is a condition of accessing these publications that users recognise and abide by the legal requirements associated with these rights.

Take down policy

The Research Portal is Queen's institutional repository that provides access to Queen's research output. Every effort has been made to ensure that content in the Research Portal does not infringe any person's rights, or applicable UK laws. If you discover content in the

Research Portal that you believe breaches copyright or violates any law, please contact openaccess@qub.ac.uk. 
Extracorporeal carbon dioxide removal for lowering the risk of mechanical ventilation: Research questions and clinical potential for the future.

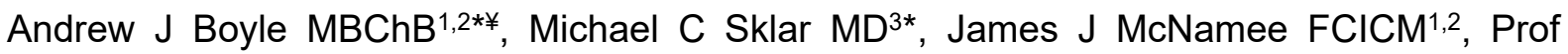
Daniel Brodie $\mathrm{MD}^{4,5}$, Prof Arthur S Slutsky MD ${ }^{3,6}$, Prof Laurent Brochard MD ${ }^{3,6}$, and Prof Daniel F McAuley MD ${ }^{1,2}$ on behalf of the International ECMO Network (ECMONet) ${ }^{* *}$.

* equal first authors.

** a full list of contributing authors can be found at the end of this manuscript.

$¥$ denotes corresponding author

1. Centre for Experimental Medicine, Queen's University Belfast, 97 Lisburn Road, Belfast. BT9 7BL. Northern Ireland

2. Regional Intensive Care Unit, Royal Victoria Hospital, 274 Grosvenor Road, Belfast, BT12 6BA. Northern Ireland

3. Interdepartmental Division of Critical Care Medicine, Department of Medicine, University of Toronto, Toronto, Canada.

4. Division of Pulmonary, Allergy, and Critical Care, Columbia University College of Physicians and Surgeons, New York, NY, USA

5. New York Presbyterian Hospital, New York, NY 10032, USA.

6. Keenan Research Center, Li Ka Shing Knowledge Institute, St. Michael's Hospital, Toronto, Canada.

\section{Corresponding author:}

Dr Andrew Boyle

Centre for Experimental Medicine,

Queen's University Belfast,

97 Lisburn Road, Belfast.

BT9 7BL.

Northern Ireland

aboyle26@qub.ac.uk

+44(0)2890245133 


\section{Summary}

As a result of technical improvements over recent years, extracorporeal carbon dioxide removal $\left(\mathrm{ECCO}_{2} \mathrm{R}\right)$ now has the potential to play an important role in the management of adults with acute respiratory failure. There is growing interest in the use of $E \mathrm{CCO}_{2} \mathrm{R}$ for the management of both hypoxaemic and hypercapnic respiratory failure. However, there is limited evidence to support its use, and several questions remain about the best way to implement this therapy that can be associated with serious side effects. This position paper reflects the consensus opinion of an international group of clinician scientists with expertise in the management of acute respiratory failure and the use of $\mathrm{ECCO}_{2} \mathrm{R}$ therapies in these settings. Following a concise review of clinically relevant aspects of $\mathrm{ECCO}_{2} \mathrm{R}$, we provide a series of recommendations for clinical practice and future research, covering topics including the practicalities of $\mathrm{ECCO}_{2} \mathrm{R}$ delivery, indications for use and service delivery. 
Key Messages ( $5-8$ bullet points)

- Extracorporeal carbon dioxide removal is an emerging therapy for the treatment of acute respiratory failure.

- There is limited evidence to support the routine use of $\mathrm{ECCO}_{2} \mathrm{R}$, outside of clinical trials, in patients with acute respiratory failure.

- Future research should focus on veno-venous $\mathrm{ECCO}_{2} \mathrm{R}$.

- Further research is required to optimise the technology and identify if modifications can be made, especially to permit the use of less anticoagulation than is currently needed.

- $\mathrm{ECCO}_{2} \mathrm{R}$ may have a role in facilitating lower tidal volume ventilation than the current standard of care in patients with acute hypoxaemic respiratory failure, but further research is required to confirm this.

- In patients with acute hypercapnic respiratory failure, $\mathrm{ECCO}_{2} \mathrm{R}$ may be used to prevent endotracheal intubation, facilitate extubation, and act as an adjunct or alternative to non-invasive ventilation.

- Clinicians are encouraged to enroll patients into clinical trials investigating the use of $\mathrm{ECCO}_{2} \mathrm{R}$ in acute respiratory failure, and contribute to data registries. 


\section{Introduction and purpose of this paper}

The use of extracorporeal carbon dioxide removal $\left(\mathrm{ECCO}_{2} \mathrm{R}\right)$ for the management of acute respiratory failure in adults is rapidly gaining interest. However, there remains a limited evidence base to support its widespread use. ${ }^{1-3}$ Many questions remain on how best to implement a therapy that may be associated with serious side effects.

This paper reflects the consensus opinion of an international group of clinician scientists with expertise in managing patients with acute respiratory failure and the use of various forms of extracorporeal life support in that setting. The aim of this position paper is to inform physicians, associated healthcare professionals, industry, and healthcare organisations about the potential role for $\mathrm{ECCO}_{2} \mathrm{R}$ in acute respiratory failure and identify where more research is required. Recommendations are provided for clinical practice (Table 1), future research (Table S1, supplementary appendix) and industry (Table S2).

\section{Historical perspective}

The concept of $\mathrm{ECCO}_{2} \mathrm{R}$ was initially proposed for three patients with refractory acute respiratory failure. ${ }^{4}$ Avoiding barotrauma was the main concern during the early development of this experimental technique. ${ }^{5,6}$ Subsequent use of $\mathrm{ECCO}_{2} \mathrm{R}$ focused on the most severe cases of hypoxaemic respiratory failure secondary to the acute respiratory distress syndrome (ARDS). ${ }^{7}$ As understanding of the harmful effects of mechanical ventilation improved, ${ }^{8,9}$ there was renewed interest in techniques that could facilitate more protective ventilation. ${ }^{10}$

\section{What is $\mathrm{ECCO}_{2} \mathrm{R}$ ?}

$\mathrm{ECCO}_{2} \mathrm{R}$ is a form of extracorporeal gas exchange that allows substantial carbon dioxide removal ( $>\sim 20 \%$ of metabolic carbon dioxide production) from the blood at relatively low blood flow rates ( 200 - $1500 \mathrm{ml} / \mathrm{min})$. It usually has minimal effects on oxygenation. This contrasts with extracorporeal membrane oxygenation (ECMO) in which significantly higher blood flow rates ( $2000-7000 \mathrm{ml} / \mathrm{min}$ ) and an oxygen-rich sweep gas allow both efficient blood oxygenation and decarboxylation. ${ }^{11} \mathrm{ECCO}_{2} \mathrm{R}$ has previously been referred to as lowflow ECMO and also a form of respiratory dialysis. ${ }^{12,13}$

\section{Carbon dioxide diffusion}

Significant carbon dioxide removal occurs during $\mathrm{ECCO}_{2} \mathrm{R}$ at blood flow rates that are a fraction of those required for full-flow ECMO because blood decarboxylation is a more 
efficient, non-limited process compared to oxygenation of blood. Carbon dioxide can be transported in solution, or bound to haemoglobin, or plasma proteins; however, the vast majority is carried within blood as bicarbonate. ${ }^{14}$ Carbonic acid results when bicarbonate complexes with hydrogen ions, and this is disassociated into carbon dioxide and water by carbonic anhydrase. Unlike the relationship between oxygen and haemoglobin, the conversion of bicarbonate into free carbon dioxide occurs with linear kinetics and the process does not become saturated, therefore allowing carbon dioxide to diffuse more efficiently from blood. This means that lower blood flow rates are sufficient to achieve carbon dioxide removal than those necessary to provide systemic oxygenation during ECMO. Furthermore, because it has greater solubility, carbon dioxide diffuses across circuit membranes with greater efficiency than oxygen. $\mathrm{ECCO}_{2} \mathrm{R}$ therefore has minimal effects on oxygenation, and the "relatively low" blood flows requires the use of smaller cannulae than ECMO.

\section{Rationale underlying the use of $\mathrm{ECCO}_{2} \mathrm{R}$}

For patients with ARDS, mechanical ventilation using lower tidal volumes with limited plateau pressure is associated with reduced hospital mortality..$^{9,15}$ In addition, lower respiratory rates may also be protective. ${ }^{16}$ These ventilation strategies reduce minute ventilation which may result in hypercapnia. Although hypercapnia is often well tolerated, ${ }^{17}$ there are a number of important side effects. ${ }^{18,19}$ Moreover, recent data have suggested an association between a partial pressure of carbon dioxide $>6.7 \mathrm{kPa}$ (in the first 48 -hours of ventilation) and increased mortality. ${ }^{20}$ Using $\mathrm{ECCO}_{2} \mathrm{R}$ to prevent hypercapnia during the delivery of lower tidal volume ventilation underpins its use in patients with acute hypoxaemic respiratory failure.

As well, in non-intubated patients with hypercapnic respiratory failure, reduction of minute ventilation by using $\mathrm{ECCO}_{2} \mathrm{R}$ can reduce intrinsic positive end-expiratory pressure, reducing the oxygen cost of breathing. ${ }^{21,22}$ These effects may all prevent the need for intubation. In intubated patients with hypercapnic respiratory failure, reduction of minute ventilation may allow earlier extubation. ${ }^{23}$ Furthermore, $\mathrm{ECCO}_{2} \mathrm{R}$ may have a function as a temporary bridging therapy prior to lung transplant for patients with hypercapnia, during the pretransplant period.

\section{Practicalities of $\mathrm{ECCO}_{2} \underline{\mathrm{R}}$}

\section{Vascular access}

Vascular access is currently most often achieved through a veno-venous (VV) configuration, with the internal jugular or femoral veins the preferred access sites. $\mathrm{ECCO}_{2} \mathrm{R}$ can usually be 
facilitated with a single, dual-lumen catheter, with lumen size dependent on the blood flow desired. The arterio-venous (AV) route has been used but the complications associated with AV-ECCO ${ }_{2} R$, such as arterial vessel damage are potentially more impactful, ${ }^{24}$ whilst the pumpless nature of these devices, entirely dependent on blood pressure, can lead to increased need for cardiovascular support. In many cases the catheter size and blood flow required for $\mathrm{ECCO}_{2} \mathrm{R}$ are much closer to those used in continuous renal replacement therapy and haemodialysis than those used for ECMO (Table 2). ${ }^{25}$

With present technology, we recommend that ultrasound-guided, aseptic placement of central catheters be used, regardless of the vascular access site, to reduce the risk of complications. ${ }^{26,27}$ We also recommend considering $\mathrm{VV}-\mathrm{ECCO}_{2} \mathrm{R}$ preferentially to $\mathrm{AV}$ $\mathrm{ECCO}_{2} \mathrm{R}$ in most circumstances.

\section{$\mathrm{ECCO}_{2} \mathrm{R}$ configuration}

Similar to haemodialysis circuits, $\mathrm{ECCO}_{2} \mathrm{R}$ devices require circuit priming (usually $<300 \mathrm{ml}$ ) prior to starting blood flow. In VV-ECCO $2 \mathrm{R}$ circuits, blood flow is generated using a blood pump, with centrifugal and roller pumps being the most common. ${ }^{14}$ Membrane lungs are designed with a mesh-like pattern, increasing the surface area for membrane lung-to-blood contact, and increasing gas exchange efficiency. The efficiency of each device (i.e. the quantity of carbon dioxide removed per minute adjusted to blood flow) should be an important consideration for clinicians since it determines the blood flow rate and hence the catheter size needed for adequate carbon dioxide removal. The properties of currently available devices are summarised in Table 2 but their respective efficiency is not well known. In patients receiving renal replacement therapy it has been demonstrated that there is no difference in catheter dysfunction or performance between jugular and femoral sites. ${ }^{28}$ However for the delivery of $\mathrm{ECCO}_{2} \mathrm{R}$, the optimal insertion site and the impact of individual factors (e.g. obesity, abdominal hypertension) remain unknown.

Additional factors that may influence device efficiency in $\mathrm{ECCO}_{2} \mathrm{R}$ include recirculation. Described during ECMO, recirculation is a phenomenon where blood that is being returned to the systemic circulation is withdrawn back into the membrane lung by the drainage catheter. ${ }^{29}$ Whilst the lower blood flow rates of $\mathrm{ECCO}_{2} \mathrm{R}$ may limit the impact of recirculation, it is possible that the use of smaller, dual-lumen catheters may increase the risk of recirculation. Recirculation could have impact on the delivery of $\mathrm{ECCO}_{2} \mathrm{R}$ in some subsets of patients.

\section{Recommendations for future research}


1. Measure the efficiency of $\mathrm{ECCO}_{2} \mathrm{R}$ devices through the quantification of carbon dioxide removed per minute and per $100 \mathrm{ml}$ of blood flow under standardized clinical conditions

2. Identify modifications that can be made to $\mathrm{ECCO}_{2} \mathrm{R}$ catheters to maximise blood flow whilst limiting complications.

3. Clarify if catheter insertion site and patient-specific factors that influence this (e.g. abdominal hypertension, patient body mass index) affect blood flow and complications.

\section{Recommendations for industry}

1. All devices should aim to integrate measurement of carbon dioxide removal and consider recirculation measurements to enable clinician titration of therapy.

2. Quantify how much carbon dioxide can be removed at different blood flows, as determined by different catheter sizes.

3. Integrate pressure measurements (e.g. drainage pressure, outlet pressure) in devices, to inform clinicians about early changes in device efficiency

\section{Anticoagulation}

Even though $\mathrm{ECCO}_{2} \mathrm{R}$ circuits are often heparin-bonded, systemic anticoagulation is required to prevent circuit thrombosis. Unfractionated heparin is typically administered to generate an activated partial thromboplastin time (aPTT) 1.5 - 2x normal although it is unknown whether this is optimal. All currently available devices require some degree of heparin to prevent thrombus formation. We recommend that suitability for systemic anticoagulation be one of the factors considered when assessing patients for $E C \mathrm{CO}_{2} \mathrm{R}$. Alternative treatment options should be sought in those patients deemed unsuitable for anticoagulation.

\section{Recommendations for future research}

1. Identify if the level of anticoagulation currently used in $\mathrm{ECCO}_{2} \mathrm{R}$ circuits can be significantly and safely reduced to limit haemorrhagic complications.

2. Investigate alternatives to heparin for anticoagulation in patients with contraindications (e.g. bleeding risks, heparin-induced thrombocytopenia).

3. Study the effects to the coagulation system during low blood-flow rates, with specific attention to the possible effects of shear stress. In addition, clarify if different levels of anticoagulation regimes are required at different blood-flow rates. 
4. Investigate the safety and effectiveness of at least partial regional anticoagulation (e.g. citrate anticoagulation ${ }^{30,31}$ ), similar to renal replacement therapy

\section{Emerging experimental techniques}

Integrating a membrane lung into a continuous renal replacement circuit to deliver $E \mathrm{CCO}_{2} \mathrm{R}$ is an emerging technique. The blood pump and anticoagulation used for continuous renal replacement are sufficient to permit some degree of $\mathrm{ECCO}_{2} \mathrm{R}$. This setup remains experimental, ${ }^{32-34}$ and further clinical trials are required.

Mechanisms to improve the effectiveness of $\mathrm{ECCO}_{2} \mathrm{R}$ have been investigated in pre-clinical studies using blood acidification (to increase carbon dioxide release) and respiratory electrodialysis combining a haemofilter, electrodialysis, and $\mathrm{ECCO}_{2} \mathrm{R}^{35-38}$ Other experimental techniques include coating the membrane lung with carbonic anhydrase, the enzyme responsible for splitting carbonic acid into carbon dioxide and water. Pre-clinical studies suggest this technique can significantly augment carbon dioxide removal across membrane lungs. ${ }^{39}$ These techniques remain experimental and should not be implemented without further research in humans.

\section{Recommendations for future research}

1. Clarify if experimental techniques to improve the efficiency of carbon dioxide removal can be safely delivered in humans receiving $\mathrm{ECCO}_{2} \mathrm{R}$, and whether they provide a clinically meaningful increase in $\mathrm{ECCO}_{2} \mathrm{R}$ efficiency in patients with acute respiratory failure.

\section{Potential indications for $\mathrm{ECCO}_{2} \mathrm{R}$}

We outline possible indications for $\mathrm{ECCO}_{2} \mathrm{R}$ below (Figure 1 ), but it is not possible currently to recommend which device should be used, nor the characteristics of a device required to achieve these.

\section{Recommendations for industry}

1. Adjust the design and characteristics of $\mathrm{ECCO}_{2} \mathrm{R}$ circuits to the indication for which it is being proposed.

\section{Acute hypoxaemic respiratory failure}

\section{Enabling lower tidal volume ventilation}


Use of a lung protective ventilation strategy is associated with reduced mortality in patients with ARDS and reduced pulmonary complications in patients without ARDS.9,15,40,41 A recent global observational study of patients with acute hypoxaemic respiratory failure suggested that lung protective ventilation is not used in all indicated patients. The use of $E C \mathrm{CO}_{2} \mathrm{R}$ to achieve lung protective ventilation may improve ventilator tolerance, reduce the need for heavy sedation and neuromuscular blockade and overall facilitate its implementation.

\section{Recommendation for future research}

1. Study the feasibility and effectiveness of $\mathrm{ECCO}_{2} \mathrm{R}$ to facilitate lung protective ventilation in patients with acute hypoxaemic respiratory failure.

2. Clarify if the use of $\mathrm{ECCO}_{2} \mathrm{R}$ in acute hypoxaemic respiratory failure improves long-term outcomes and quality of life.

\section{Facilitating lower than standard of care tidal volume ventilation}

Mechanical ventilation using a tidal volume of $6 \mathrm{ml} / \mathrm{kg}$ predicted body weight (PBW) is regarded as best practice for patients with hypoxaemic respiratory failure meeting criteria for ARDS. It is possible that further reductions in tidal volume and plateau pressure may improve clinical outcomes in many patients. ${ }^{13,42} \mathrm{~A}$ systematic review confirmed that although there was a consistent physiological effect in observational studies of $E \mathrm{CCO}_{2} R$ in ARDS, the outcome data were variable. ${ }^{1}$ A multi-centre randomized, controlled clinical trial of 79 patients with ARDS comparing a standard lung protective ventilation strategy (6ml/kg PBW) with tidal volumes of $3 \mathrm{ml} / \mathrm{kg}$ PBW plus $\mathrm{AV}-\mathrm{ECCO} \mathrm{CO}_{2} \mathrm{R}$ did not demonstrate a difference in outcome between groups. However, a post-hoc subgroup analysis of patients with a ratio of partial pressure of arterial blood oxygen content to inspired fraction of oxygen $\left(\mathrm{PaO}_{2} / \mathrm{FiO}_{2}\right.$ ratio) $\leq 20 \mathrm{kPa}$ suggested a benefit of the lower tidal volume strategy. ${ }^{43}$ These findings suggest these patients may benefit from greater lung protection. ${ }^{10,42}$

There are several relevant ongoing clinical trials, which will potentially better inform clinicians. The REST trial (NCT02654327) is randomizing adult patients with acute hypoxaemic respiratory failure $\left(\mathrm{PaO}_{2} / \mathrm{FiO}_{2}\right.$ ratio $\left.<20 \mathrm{kPa}\right)$ to either conventional lungprotective ventilation, or $\mathrm{V}$ - $E \mathrm{CCO}_{2} \mathrm{R}$ plus lower tidal volume ventilation. ${ }^{44} \mathrm{~A}$ European feasibility and safety study was completed in 2017 , investigating the role of $V V-E C C_{2} R$ in adult patients with at least moderate ARDS (SUPERNOVA, NCT02654327) with the aim of reducing tidal volumes to $4 \mathrm{ml} / \mathrm{kg}$. Table 3 provides a list of trials which are either planned, in progress or completed but with results as yet unpublished. 
There is insufficient evidence at present to inform clinicians about the role of $E_{C C O} R$ in acute hypoxaemic respiratory failure. Currently, we do not recommend its routine use, and support the recommendations of the United Kingdom National Institute for Health and Care Excellence, and consensus guidelines from the French Intensive Care Society, that recommend patients receiving $\mathrm{ECCO}_{2} \mathrm{R}$ should do so as part of a clinical trial. ${ }^{45,46}$

\section{Recommendations for future research}

1. Evaluate if using $\mathrm{ECCO}_{2} \mathrm{R}$ to enable mechanical ventilation with lower than current standard of care tidal volumes, improves outcomes in patients with moderate to severe acute hypoxaemic respiratory failure.

2. Investigate which subsets of patients with acute hypoxaemic respiratory failure may benefit from lower than standard of care tidal volume ventilation facilitated by $\mathrm{ECCO}_{2} \mathrm{R}$.

\section{Acute hypercapnic respiratory failure}

Chronic Obstructive Pulmonary Disease (COPD)

Acute hypercapnic respiratory failure in patients with COPD, is another potential indication for $\mathrm{ECCO}_{2} \mathrm{R}$. Although non-invasive ventilation is very effective in these patients, $5-20 \%$ require intubation, ${ }^{47,48}$ and these patients have an in-hospital mortality of approximately $30 \% .{ }^{48}$

A systematic review of case series' and case-control studies demonstrated that non-invasive ventilation with adjunctive $\mathrm{ECCO}_{2} \mathrm{R}$ therapy prevented intubation in $93 \%$ of patients with COPD. ${ }^{2}$ In addition, preliminary, retrospective data suggest there may be economic benefit in using $\mathrm{ECCO}_{2} \mathrm{R}$ to avoid invasive mechanical ventilation, because it reduces intensive care unit and hospital length of stay. ${ }^{49}$

The use of $\mathrm{ECCO}_{2} \mathrm{R}$ for facilitating extubation from invasive mechanical ventilation in hypercapnic COPD patients is another potential indication. In an elegant physiological demonstration, $\mathrm{ECCO}_{2} \mathrm{R}$ reduced respiratory muscle work and carbon dioxide production in intubated patients during weaning. ${ }^{50}$ Two pilot studies have demonstrated it is feasible to use $\mathrm{ECCO}_{2} \mathrm{R}$ to facilitate extubation in patients with COPD. ${ }^{23,51}$ Further data is necessary before this approach could be considered standard of care for these patients. A list of planned, or in progress, clinical trials is provided in Table 4 . It is possible that using $\mathrm{ECCO}_{2} \mathrm{R}$ to facilitate extubation may also have a role in acute hypoxaemic respiratory failure.

\section{Recommendations for future research}


1. Undertake clinical trials to study the role of $\mathrm{ECCO}_{2} \mathrm{R}$ in acute hypercapnic respiratory failure (such as COPD exacerbation), including:

a. Identify if it can be safely and effectively used in combination with noninvasive ventilation to prevent the requirement for invasive mechanical ventilation. Furthermore, identify factors (e.g. clinical and physiological factors) which may predict the failure of $\mathrm{ECCO}_{2} \mathrm{R}$ in preventing invasive mechanical ventilation.

b. Establish if $\mathrm{ECCO}_{2} \mathrm{R}$ can facilitate extubation from invasive mechanical ventilation.

c. Clarify if the use of $E \mathrm{CCO}_{2} \mathrm{R}$ in acute hypercapnic respiratory failure has a mortality benefit, improves long-term functional recovery and quality of life as an adjunct in both invasive and non-invasive ventilation.

\section{Asthma}

Severe life-threatening asthma is characterized by bronchospasm, airflow obstruction and hypercapnia. In a very selected patient group who are refractory to conventional asthma management, the provision of $\mathrm{ECCO}_{2} \mathrm{R}$ could potentially mitigate severe life-threatening exacerbations by minimizing dynamic hyperinflation and intrinsic positive end expiratory pressure. The current body of literature in this area however is limited to case reports of asthmatics already receiving invasive mechanical ventilation and subsequently assisted with $\mathrm{ECCO}_{2} \mathrm{R}^{52-55}$

\section{Recommendations for future research}

1. Establish whether $\mathrm{ECCO}_{2} \mathrm{R}$ can prevent the requirement for invasive mechanical ventilation, and whether this is associated with improved clinical outcomes, in status asthmaticus. However, undertaking studies within this population may be challenging.

2. Study the role $\mathrm{ECCO}_{2} \mathrm{R}$ may have to facilitate extubation from invasive mechanical ventilation and whether this is associated with improved clinical outcomes in severe status asthmaticus.

\section{Bridge to Lung Transplantation}

There is a strong rationale for considering $\mathrm{ECCO}_{2} \mathrm{R}$ as a bridge to lung transplantation in patients with decompensated respiratory failure, but data supporting its use in these patients is limited. A retrospective analysis of 20 patients bridged with $\mathrm{ECCO}_{2} \mathrm{R}$ whilst awaiting lung transplant demonstrated an improvement in hypercapnia and acidosis within the first twelve hours of application. After a bridging period ranging from four to eleven days, 19 patients 
(95\%) were successfully transplanted, and hospital survival was $75 \%{ }^{56}$ In a cohort of 72 patients awaiting lung transplantation in whom extracorporeal support was used, $70 \%$ of patients participated in daily physical activity, significantly higher rates of ambulation were observed compared to unsupported patents, and two year survival was $84 \% .^{57}$

\section{Recommendations for future research}

1. Identify if $\mathrm{ECCO}_{2} \mathrm{R}$ can be used as bridge to lung transplantation.

\section{Complications associated with $\mathrm{ECCO}_{2} \mathrm{R}$}

$\mathrm{ECCO}_{2} \mathrm{R}$ may be associated with a range of complications and we provide a summary of these in Table 5.

\section{Catheter-specific}

The risk of complications related to catheter insertion differ significantly between arterial and venous insertion sites, but complications from both include bleeding, infection and catheter dislodgement. Arterial catheterisation is associated with more risk, and complications include distal limb ischaemia, compartment syndrome and pseudo-aneurysm formation. This risk may be mitigated by using smaller calibre catheters. As technology develops there is hope that catheter size will be reduced further, leading to the incidence of catheter-related complications that will approach that of central venous catheters. ${ }^{58}$ Although safety data from the Xtravent study are reassuring (three patients experienced catheter-specific complications), ${ }^{43}$ the increased risk associated with $\mathrm{AV}-\mathrm{ECCO}_{2} \mathrm{R}$ contribute to our recommendation that it should be avoided beyond centres already familiar with this technology.

\section{Bleeding risk}

Despite the use of heparin-bonded circuits, patients receiving $\mathrm{ECCO}_{2} \mathrm{R}$ usually require lowlevel. It is unclear whether haemorrhagic complications are more common with ECMO or with $\mathrm{ECCO}_{2} \mathrm{R}$, however the evidence base for this is limited. In a recent clinical trial comparing ECMO to conventional care for the treatment of severe ARDS, there was no difference between groups in the rates of massive bleeding or haemorrhagic stroke, although patients receiving ECMO did experience more episodes of bleeding that necessitated blood transfusion. ${ }^{59}$ An observational study of patients receiving ECMO for severe respiratory failure demonstrated that most patients had intracranial haemorrhage at admission to ICU, suggesting that the risk of intracranial haemorrhage is associated with illness severity rather than the application of ECMO. ${ }^{60}$ 
In studies of $\mathrm{ECCO}_{2} \mathrm{R}$ to-date, the rate of significant haemorrhagic complications range between 2 - 50\%. ${ }^{1,2}$ In a recent pilot study of $\mathrm{VV}-\mathrm{ECCO}_{2} \mathrm{R}$, there were bleeding complications necessitating blood transfusion in $40 \%$ of patients, although none were deemed significant and no patient experienced haemodynamic compromise. ${ }^{61}$ However, in one older study all twenty-one patients who received $\mathrm{V}-\mathrm{ECCO}_{2} \mathrm{R}$ experienced haemorrhagic complications, and it was necessary to discontinue therapy in seven patients. ${ }^{7}$ In a small observational study of patients treated with the Hemolung Respiratory Assist System, four of seven patients had clinically relevant bleeding. Thrombocytopenia, factor XII deficiency and acquired von-Willebrand syndrome were identified during therapy, with spontaneous recovery after $\mathrm{ECCO}_{2} \mathrm{R}$ was discontinued. ${ }^{62}$ Currently, we strongly recommend regular monitoring of coagulation indices in all patients receiving $\mathrm{ECCO}_{2} \mathrm{R}$, with cessation of therapy when there is significant bleeding.

\section{Haemolysis}

Modern $\mathrm{ECCO}_{2} \mathrm{R}$ pumps and circuits are designed to limit the shear force applied to blood as it passes through the pump. However there remains a significant risk of haemolysis and clot formation, and this risk may be greater at lower blood-flow rates. It is recommended that in patients with decreasing haemoglobin, screening for haemolysis occurs (e.g. free haemoglobin, lactate dehydrogenase) as part of clinically relevant investigations for an underlying cause. Haemolysis is known to be associated with acute kidney injury (AKI), ${ }^{63}$ however it is unknown if the degree of haemolysis induced by $\mathrm{ECCO}_{2} \mathrm{R}$ is associated with $A K I$, or the frequency of $A K I$, in this setting. The ongoing need for $\mathrm{ECCO}_{2} \mathrm{R}$ should be reviewed in all patients with circuit-induced haemolysis.

\section{Recommendations for future research}

1. Clarify the risks (e.g. vascular complications, haematological) associated with modern $\mathrm{ECCO}_{2} \mathrm{R}$ devices, particularly in $\mathrm{VV}$-circuits. This should be considered a research priority.

2. Identify if there is a risk of haemolysis-induced renal function during $\mathrm{ECCO}_{2} \mathrm{R}$ therapy.

Ongoing and future clinical trials utilising modern $\mathrm{ECCO}_{2} \mathrm{R}$ devices will better inform clinicians about the risks associated with this technology (Tables 3 and 4).

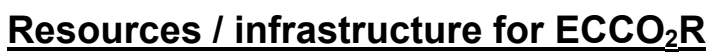 \\ Who and what is needed to deliver $\mathrm{ECCO}_{2} \mathrm{R}$ ?}


A team of highly motivated and trained physicians, registered nurses, respiratory therapists and physiotherapists is required for the safe and effective delivery of $\mathrm{ECCO}_{2} \mathrm{R}$. Similar to the recommendations for $\mathrm{ECMO},{ }^{64}$ every member of staff treating patients receiving $\mathrm{ECCO}_{2} \mathrm{R}$ should have received $\mathrm{ECCO}_{2} \mathrm{R}$-specific training, and demonstrate ongoing competencies. We also recommend that an attending physician with experience in managing patients on $\mathrm{ECCO}_{2} \mathrm{R}$ should be available to provide 24-hour coverage. Team members will require ultrasonographic vascular access skills for percutaneous cannulation. Importantly, and unlike ECMO, a dedicated perfusionist is typically not required to manage the $E C \mathrm{CO}_{2} \mathrm{R}$ circuit, but may be an important part of the team in some centres.

As it is still mainly a research tool, at present $\mathrm{ECCO}_{2} \mathrm{R}$ should be delivered within the setting of a clinical trial. Each centre should have the necessary expertise to manage the $\mathrm{ECCO}_{2} \mathrm{R}$ device, and its complications. This is in contrast to the recommendations for delivering ECMO, where therapy delivered in expert centres may be associated with improved safety and outcomes. ${ }^{64-67}$ We recommend those using $\mathrm{ECCO}_{2} \mathrm{R}$ should be proficient in the delivery of continuous renal replacement therapies.

\section{Training requirements for implementing $\mathrm{ECCO}_{2} \mathrm{R}$ within a critical care environment}

It is anticipated that much like renal replacement therapy, the provision of $\mathrm{ECCO}_{2} \mathrm{R}$ for acute respiratory failure will be met by critical care units. Staff require appropriate training to manage the patient, the device, and to recognize relevant complications. For example in the REST trial training was delivered by a team of experienced clinicians and support staff. ${ }^{44}$ Delivering training in batches allowed units to establish a core set of staff who were skilled in the management of patients receiving $\mathrm{ECCO}_{2} \mathrm{R}$. We recommend that a specific training programme delivered by staff experienced in managing patients receiving $\mathrm{ECCO}_{2} \mathrm{R}$ for acute respiratory failure should occur within each unit delivering $\mathrm{ECCO}_{2} \mathrm{R}$. The training programme should be at least as extensive as that delivered for renal replacement therapy, and should include device-specific training and associated complications. After establishing an $\mathrm{ECCO}_{2} \mathrm{R}$ service, staff competency should be regularly assessed.

\section{Program evaluation and quality assurance}

Delivering a safe and effective service is of paramount importance. Should $\mathrm{ECCO}_{2} \mathrm{R}$ become routine in the management of acute respiratory failure, there will need to be robust evaluation and quality assurance programmes. We support the recommendations from a previous position paper for the organisation of ECMO services and believe similar processes should be considered for regular review of $\mathrm{ECCO}_{2} \mathrm{R}$ services. ${ }^{64}$ In brief, evaluation programmes should include regular review of outcomes for patients receiving $E C \mathrm{CO}_{2} \mathrm{R}$, 
prompt review of any significant adverse event associated with $E \mathrm{CCO}_{2} \mathrm{R}$, and regional/national unit accreditation. These should take place in addition to each unit's local evaluation and quality assurance programmes. Sites using $\mathrm{ECCO}_{2} \mathrm{R}$ as part of clinical care should be strongly encouraged to input data into a registry (e.g. Extracorporeal Life Support Organisation www.elso.org) to facilitate quality assurance.

\section{Recommendations for future research:}

1. Establish appropriate outcome measures to evaluate the safety of an $\mathrm{ECCO}_{2} \mathrm{R}$ service

\section{Summary of recommendations and research questions}

$\mathrm{ECCO}_{2} \mathrm{R}$ is a novel and attractive technique for the management of respiratory failure but there is a paucity of evidence to support its routine application. In keeping with recommendations from the United Kingdom National Institute for Health and Care Excellence and consensus guidelines from the French Intensive Care Society, which encourage clinicians to enrol patients into ongoing clinical trials and to collaborate in data collection initiatives (e.g. the Extracorporeal Life Support Organization registry), ${ }^{45,46}$ we believe the use of $\mathrm{ECCO}_{2} \mathrm{R}$ in the clinical setting should be primarily confined within research protocols. Organisations such as the International ECMO Network (ECMONet; www.internationalecmonetwork.org) can help to conduct the necessary studies and to coordinate collaboration in this arena.

\section{Search strategy and selection criteria}

The authors searched PubMed for the terms "acute respiratory failure" [All Fields] AND / OR "extra-corporeal carbon dioxide removal" [All Fields], "renal replacement therapy" [All Fields\} and "haemolysis" [All Fields] with no restriction on language or date. This search was performed on $10^{\text {th }}$ December 2017, and updated on $10^{\text {th }}$ June 2018. References were also searched from within existing systematic reviews. 
Table 1: Summary of recommendations for clinical practice

\begin{tabular}{|c|c|}
\hline & Recommendations \\
\hline $\begin{array}{l}\text { Practicalities of } \mathrm{ECCO}_{2} \mathbf{R} \\
\text { (Vascular access, circuit } \\
\text { configuration, } \\
\text { anticoagulation, emerging } \\
\text { experimental techniques) }\end{array}$ & $\begin{array}{l}\text { - Use ultrasound-guided, aseptic central catheter placement } \\
\text { - Consider } \mathrm{VV}-\mathrm{ECCO} \mathrm{CO}_{2} \mathrm{R} \text { over } \mathrm{AV}-\mathrm{ECCO}_{2} \mathrm{R} \\
\text { - } \mathrm{AV}-\mathrm{ECCO} 2 \mathrm{R} \text { should be avoided beyond centres already } \\
\text { familiar with this technology } \\
\text { - Alternative treatment options should be sought for patients } \\
\text { deemed unsuitable to receive anticoagulation. } \\
\text { - We strongly recommend regular monitoring of indices of } \\
\text { coagulation in all patients receiving } \mathrm{ECCO}_{2} \mathrm{R} \\
\text { Cease therapy where there is a concern regarding } \\
\text { significant bleeding }\end{array}$ \\
\hline $\begin{array}{l}\text { Acute hypoxaemic } \\
\text { respiratory failure }\end{array}$ & $\begin{array}{l}\text { - There is insufficient evidence to recommend the routine } \\
\text { use of } \mathrm{ECCO}_{2} \mathrm{R} \text { in patients with acute hypoxaemic } \\
\text { respiratory failure }\end{array}$ \\
\hline $\begin{array}{l}\text { Acute hypercapnic } \\
\text { respiratory failure }\end{array}$ & $\begin{array}{l}\text { - Further data is necessary before } \mathrm{ECCO}_{2} \mathrm{R} \text { use could be } \\
\text { considered standard of care }\end{array}$ \\
\hline $\begin{array}{l}\text { Clinical trial / registry } \\
\text { enrolment }\end{array}$ & $\begin{array}{l}\text { - Clinicians are strongly encouraged to recruit eligible } \\
\text { patients to clinical trials of } \mathrm{ECCO}_{2} \mathrm{R} \text {, or contribute data } \\
\text { from non-trial patients receiving } \mathrm{ECCO}_{2} \mathrm{R} \text { to international } \\
\text { registries (e.g. ELSO) }\end{array}$ \\
\hline Service delivery & $\begin{array}{l}\text { - Centres using } \mathrm{ECCO}_{2} \mathrm{R} \text { should be proficient in the delivery } \\
\text { of continuous renal replacement therapies } \\
\text { - An attending physician with experience of } \mathrm{ECCO}_{2} \mathrm{R} \text { should } \\
\text { be available to provide 24-hour coverage } \\
\text { - A specific training programme, delivered by staff } \\
\text { experienced in managing patients receiving } \mathrm{ECCO} 2 \mathrm{R} \text { for } \\
\text { acute respiratory failure, should occur within each unit } \\
\text { delivering an } \mathrm{ECCO}_{2} \mathrm{R} \text { service }\end{array}$ \\
\hline Program evaluation & $\begin{array}{l}\text { - Providers of } \mathrm{ECCO}_{2} \mathrm{R} \text { services should regularly review } \\
\text { outcomes of all patients receiving therapy, with prompt } \\
\text { review of any associated significant adverse event. }\end{array}$ \\
\hline
\end{tabular}


Table 2: Examples of available $\mathrm{ECCO}_{2} \mathrm{R}$ devices

\begin{tabular}{|c|c|c|c|c|c|c|}
\hline Company & Device & $\begin{array}{l}\text { Flow Rates } \\
(\mathrm{ml} / \mathrm{min})\end{array}$ & $\begin{array}{l}\text { Catheter } \\
\text { Size } \\
(\mathrm{Fr}){ }^{*}\end{array}$ & $\begin{array}{l}\text { Preferred } \\
\text { Insertion Site } \\
*\end{array}$ & $\begin{array}{l}\text { Membrane } \\
\text { Size } \\
\left(\mathrm{m}^{2}\right)\end{array}$ & Potential Indications \\
\hline ALung & $\begin{array}{l}\text { Hemolung } \\
\text { Respiratory } \\
\text { Assist System }\end{array}$ & $350-550$ & $\begin{array}{l}15 \\
5\end{array}$ & $\begin{array}{l}\text { Femoral, } \\
\text { internal jugular }\end{array}$ & 0.59 & $\begin{array}{l}\text { 1. Hypercapnic respiratory failure refractory to NIV } \\
\text { 2. Facilitate lung protective ventilation during IMV }\end{array}$ \\
\hline $\begin{array}{l}\text { Novalung / } \\
\text { Fresenius }\end{array}$ & AV-iLA ${ }^{a}$ & $100-1500$ & $13-17$ & Femoral & $1 \cdot 3$ & $\begin{array}{l}\text { 1. Lower tidal volume ventilation in ARDs } \\
\text { 2. Weaning from IMV } \\
\text { 3. COPD exacerbations } \\
\text { 4. Bridge to lung transplant }{ }^{b} \\
\text { 5. Bronchopleural fistula }\end{array}$ \\
\hline $\begin{array}{l}\text { Novalung / } \\
\text { Fresenius }\end{array}$ & $\begin{array}{l}\text { iLA miniLung } \\
\text { petite kit }\end{array}$ & $100-800$ & 18 & Internal jugular & 0.32 & $\begin{array}{l}\text { 1. Lower tidal volume ventilation in ARDS } \\
\text { 2. Weaning from IMV } \\
\text { 3. Avoid intubation } \\
\text { 4. Bridge to lung transplant }\end{array}$ \\
\hline $\begin{array}{l}\text { Novalung / } \\
\text { Fresenius }\end{array}$ & $\begin{array}{l}\text { iLA / Novalung } \\
\text { miniLung kit }{ }^{c}\end{array}$ & $350-2400^{d}$ & $18-24$ & $\begin{array}{l}\text { Femoral, } \\
\text { internal jugular }\end{array}$ & 0.65 & $\begin{array}{l}\text { 1. Lower tidal volume ventilation in ARDS } \\
\text { 2. Weaning from IMV } \\
\text { 3. Avoid intubation } \\
\text { 4. Bridge to lung transplant }\end{array}$ \\
\hline $\begin{array}{l}\text { Novalung / } \\
\text { Fresenius }\end{array}$ & iLA activve & $500-4500$ & $13-24$ & $\begin{array}{l}\text { Femoral, } \\
\text { internal jugular }\end{array}$ & $1 \cdot 3$ & $\begin{array}{l}\text { 1. Lower tidal volume ventilation in ARDS } \\
\text { 2. Weaning from IMV } \\
\text { 3. Avoid intubation } \\
\text { 4. Bridge to lung transplant }\end{array}$ \\
\hline
\end{tabular}




\begin{tabular}{|l|l|l|l|l|l|l|}
\hline ESTOR & ProLUNG & $<450$ & $13 \cdot 5$ & $\begin{array}{l}\text { Femoral, } \\
\text { internal jugular }\end{array}$ & $1 \cdot 8$ & $\begin{array}{l}\text { 1. Moderate ARDS } \\
\text { 2. COPD exacerbations: Prevent IMV, facilitate } \\
\text { weaning } \\
\text { 3ridge to and post lung transplant } \\
\text { Bronchopleural fistula or other airway lesions }\end{array}$ \\
\hline Baxter & PrismaLung ${ }^{\mathrm{C}}$ & $<450$ & $13-14$ & Internal jugular & $0 \cdot 32$ & 1 Physician discretion \\
\hline BBraun & Diapact & $200-500$ & 13 & $\begin{array}{l}\text { Femoral, } \\
\text { internal jugular }\end{array}$ & $1 \cdot 35-1 \cdot 8$ & $\begin{array}{l}\text { 1. Moderate ARDS } \\
\text { 2. COPD exacerbations: Prevent IMV, facilitate } \\
\text { weaning } \\
\text { 3ridge to and post lung transplant } \\
\text { 3ronchopleural fistula or other airway lesions }\end{array}$ \\
\hline
\end{tabular}

IMV: Invasive mechanical ventilation; NIV: Non-invasive ventilation; COPD: Chronic obstructive pulmonary disease; ARDS: Acute respiratory distress syndrome.

${ }^{*}$ Catheter size and insertion site may depend on individual patient factors.

a. Pumpless system.

b. This device has been used in a pulmonary artery - left atrium configuration as a bridge to lung transplant in patients with pulmonary hypertension.

c. iLA miniLung and Novalung miniLung are two different devices that share similar characteristics.

d. Flow rates of $1200-2400 \mathrm{ml}$ require $3 / 8$ connector size.

e. This device is used in conjunction with the Prismaflex® control unit during continuous renal replacement therapy or haemopurification. 
Table 3: Ongoing, planned or unpublished clinical trials investigating acute hypoxaemic respiratory failure

\begin{tabular}{|c|c|c|c|c|c|c|c|}
\hline Trial Name & $\begin{array}{l}\text { Registration } \\
\text { details }\end{array}$ & Population & Enrolment & $\begin{array}{l}\text { 1. Intervention } \\
\text { 2. Target }\end{array}$ & Comparator & Primary outcome & Status \\
\hline $\begin{array}{l}\text { pRotective } \\
\text { vEntilation with } \\
\text { veno-venouS } \\
\text { lung assisT in } \\
\text { respiratory } \\
\text { failure (The } \\
\text { REST Study) }\end{array}$ & $\begin{array}{l}\text { NCT02654327 } \\
\text { ISRCTN31262122 }\end{array}$ & $\begin{array}{l}\text { Mechanically } \\
\text { ventilated adult } \\
\text { patients within } 48 \\
\text { hours of acute } \\
\text { hypoxaemic } \\
\text { respiratory failure } \\
\left(\mathrm{PaO}_{2} / \mathrm{FiO}_{2} \text { ratio < }\right. \\
20 \mathrm{kPa}) \text { receiving at } \\
\text { least PEEP of } 5\end{array}$ & 1120 & $\begin{array}{l}\text { 1. } \mathrm{VV}-\mathrm{ECCO} \mathrm{CO}_{2} \mathrm{R} \\
\text { 2. } \mathrm{Vt} \leq 3 \mathrm{ml} / \mathrm{kg} \text { PBW } \\
\text { and a Pplat } \leq \\
25 \mathrm{cmH}_{2} \mathrm{O}, \\
\text { maintaining the } \\
\text { arterial } \mathrm{pH} \geq 7.20\end{array}$ & $\begin{array}{l}\text { Standard } \\
\text { ventilation (Vt } \\
6 \mathrm{ml} \mathrm{/} \mathrm{kg} \\
\mathrm{PBW})\end{array}$ & 90-day mortality & Recruiting \\
\hline $\begin{array}{l}\text { Ultra-protective } \\
\text { Pulmonary } \\
\text { Ventilation } \\
\text { Supported by } \\
\text { Low Flow } \\
\mathrm{ECCO}_{2} \mathrm{R} \text { for } \\
\text { Severe ARDS } \\
\text { (U-Protect) }\end{array}$ & NCT02252094 & $\begin{array}{l}\text { Mechanically } \\
\text { ventilated adults } \\
\text { with at least } \\
\text { moderate ARDS, } \\
\text { reversible disease, } \\
\text { expected to be } \\
\text { ventilated for }>48 \\
\text { hours. }\end{array}$ & 50 & 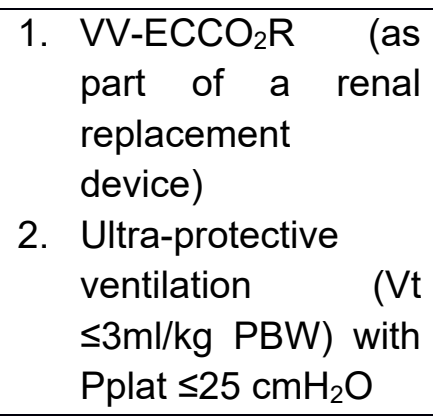 & $\begin{array}{l}\text { Standard } \\
\text { ventilation } \\
(6 \mathrm{ml} / \mathrm{kg} \\
\mathrm{PBW})\end{array}$ & $\begin{array}{l}\text { Ability to achieve } \\
\text { Pplat }<25 \mathrm{cmH}_{2} \mathrm{O}\end{array}$ & Recruiting \\
\hline $\begin{array}{l}\text { Strategy of } \\
\text { UltraProtective } \\
\text { lung ventilation } \\
\text { with } \\
\text { Extracorporeal } \\
\mathrm{CO}_{2} \text { Removal } \\
\text { for New-Onset } \\
\text { moderate to }\end{array}$ & NCT02282657 & $\begin{array}{l}\text { Mechanically } \\
\text { ventilated adults } \\
\text { with an expected } \\
\text { ventilation duration } \\
>24 \text { hours, whom } \\
\text { have moderate } \\
\text { ARDS }\left(\mathrm{PaO}_{2} / \mathrm{FiO}_{2}\right. \\
\text { ratio } 13.33 \quad-\end{array}$ & $\begin{array}{l}\text { Pilot study: } \\
95\end{array}$ & $\begin{array}{l}\text { 1. 2-hour run in period } \\
\text { followed by } \mathrm{AV} \text { - or } \\
\mathrm{VV}-\mathrm{ECCO} \mathrm{CO}_{2} \mathrm{R} \\
\text { 2. Reduction in tidal } \\
\text { volume }( \pm \\
\text { respiratory rate) } \\
\text { maintaining } \mathrm{Pplat}^{-} \\
23-25 \text {, and } \mathrm{PaCO}_{2}\end{array}$ & Nil & $\begin{array}{l}\mathrm{Vt} \text { reduction to } 4 \\
\mathrm{~mL} / \mathrm{kg} \text {, maintaining } \\
\mathrm{pH} \text { and } \mathrm{PaCO}_{2} \text { to } \\
\pm 20 \% \text { of baseline. }\end{array}$ & $\begin{array}{l}\text { Completed } \\
\text { but } \\
\text { unpublished }\end{array}$ \\
\hline
\end{tabular}




\begin{tabular}{|c|c|c|c|c|c|c|c|}
\hline $\begin{array}{l}\text { seVere ARDS } \\
\text { (SUPERNOVA) }\end{array}$ & & $26 \cdot 67 \mathrm{kPa})$ & & at baseline $( \pm 20 \%)$ & & & \\
\hline $\begin{array}{lr}\text { Low-Flow } & \mathrm{CO}_{2} \\
\text { Removal } & \text { for } \\
\text { Mild } & \text { to } \\
\text { Moderate } & \\
\text { ARDS } & \text { With } \\
\text { PRISMALUNG }\end{array}$ & NCT02606240 & $\begin{array}{l}\text { Mechanically } \\
\text { ventilated adults } \\
\text { with mild to } \\
\text { moderate ARDS, } \\
\text { expected to be } \\
\text { mechanically } \\
\text { ventilated for }>24 \\
\text { hours. }\end{array}$ & 20 & $\begin{array}{l}\text { 1. } \mathrm{VV}-\mathrm{ECCO}_{2} \mathrm{R} \text { (as } \\
\text { part of a renal } \\
\text { replacement) } \\
\text { 2. Ultra-protective } \\
\text { ventilation (Vt } \\
\begin{array}{l}\text { 4ml/kg PBW, Pplat } \\
\left.23-5 \mathrm{cmH}_{2} \mathrm{O}\right)\end{array}\end{array}$ & Nil & 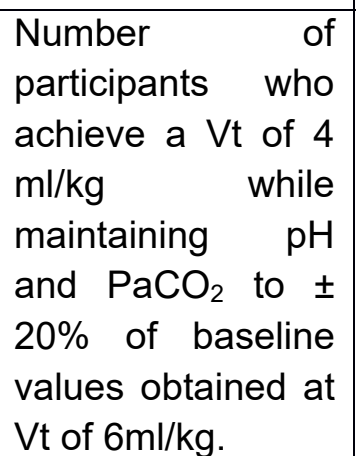 & $\begin{array}{l}\text { Completed } \\
\text { but } \\
\text { unpublished }\end{array}$ \\
\hline $\begin{array}{l}\text { "Low Flow" } \mathrm{CO}_{2} \\
\text { Removal on } \\
\text { RRT } \\
\text { (Prismalung) }\end{array}$ & NCT02590575 & $\begin{array}{l}\text { Mechanically } \\
\text { ventilated adults, } \\
\text { expected to be } \\
\text { ventilated for }>24 \\
\text { hours, with a } \\
\mathrm{PaCO}_{2} \geq 55 \mathrm{mmHg} \text {, } \\
\text { plateau pressure } \\
>25 \mathrm{cmH}_{2} \mathrm{O} \text {, and } \\
\mathrm{pH}<7 \cdot 30 \text {, who } \\
\text { require renal } \\
\text { replacement } \\
\text { therapy. }\end{array}$ & 20 & 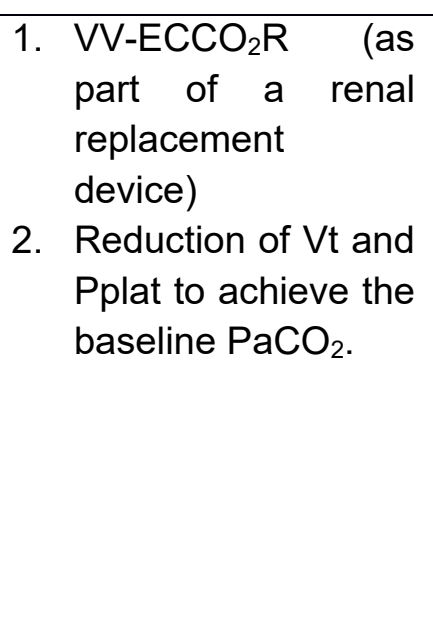 & Nil & $\begin{array}{l}\text { Changes } \\
\mathrm{PaCO}_{2} \text {, acid-base } \\
\text { status, Vt and } \\
\text { Pplat }\end{array}$ & $\begin{array}{l}\text { Completed } \\
\text { but } \\
\text { unpublished }\end{array}$ \\
\hline $\begin{array}{l}\text { Correction by } \\
\text { ECCO2-R of } \\
\text { Hypercapnia in } \\
\text { Patients With } \\
\text { DVP in }\end{array}$ & NCT03303807 & \begin{tabular}{l}
\multicolumn{2}{l}{ Moderate-severe } \\
ARDS with \\
pulmonary \\
vascular \\
dysfunction on
\end{tabular} & 20 & $\begin{array}{l}\text { 1. } \mathrm{WV}-\mathrm{ECCO}{ }_{2} \mathrm{R} \text { (as } \\
\text { part of a renal } \\
\text { replacement device) } \\
\text { 2. Correction of } \\
\text { hypercapnia under }\end{array}$ & Nil & $\begin{array}{lr}\begin{array}{l}\text { Percentage } \\
\text { patients }\end{array} & \text { with } \\
\text { corrected } & \\
\text { hypercapnia } & \\
\text { (defined as } & 20 \%\end{array}$ & $\begin{array}{ll}\text { Not yet } \\
\text { recruiting }\end{array}$ \\
\hline
\end{tabular}




\begin{tabular}{|c|c|c|c|}
\hline $\begin{array}{l}\text { Moderate to } \\
\text { Severe ARDS } \\
\text { Under } \\
\text { Protective } \\
\text { Ventilation. } \\
\text { (COVAP) }\end{array}$ & $\begin{array}{l}\text { echocardiography } \\
\text { and refractory } \\
\text { hypercapnia } \\
\left(\mathrm{PaCO}_{2} \geq 6 \cdot 4 \mathrm{kPa}\right)\end{array}$ & $\begin{array}{l}\text { protective ventilation } \\
\text { (tidal volume } 6 \mathrm{ml} / \mathrm{kg} \\
(\mathrm{PBW}), \quad \text { plateau } \\
\text { pressure } \\
\leq 30 \mathrm{cmH}_{2} \mathrm{O} \text { ) }\end{array}$ & $\begin{array}{l}\text { decrease in } \\
\mathrm{PaCO}_{2} \text { two hours } \\
\text { after initiation of } \\
\left.\mathrm{ECCO}_{2} \mathrm{R}\right)\end{array}$ \\
\hline
\end{tabular}

PEEP: Positive end-expiratory pressure; VV-ECCO 2 R: veno-venous extracorporeal carbon dioxide removal; PBW: Predicted body weight; Vt: Tidal volume; Pplat: plateau pressure; ARDS: Acute respiratory distress syndrome; COPD: chronic obstructive pulmonary disease; DVP: Pulmonary vascular dysfuncton. 
Table 4: Ongoing or planned clinical trials investigating acute hypercapnic respiratory failure

\begin{tabular}{|c|c|c|c|c|c|c|c|}
\hline Trial Name & $\begin{array}{l}\text { Registration } \\
\text { details }\end{array}$ & Population & Enrolment & Intervention & Comparator & $\begin{array}{l}\text { Primary } \\
\text { outcome }\end{array}$ & Status \\
\hline $\begin{array}{l}\mathrm{ECCO}_{2} \mathrm{R} \text { as an Adjunct } \\
\text { to NIV in AECOPD }\end{array}$ & NCT02086084 & $\begin{array}{l}\text { Adults with acute } \\
\text { exacerbation of COPD, with } \\
\text { persistent arterial } \mathrm{pH}<7.30 \\
\text { primarily due to hypercapnic } \\
\text { respiratory failure after } \\
\text { standard therapy and at } \\
\text { least } 1 \text { hour of NIV }\end{array}$ & 24 & $\begin{array}{l}\text { VV-ECCO } 2 \mathrm{R}+ \\
\text { NIV }\end{array}$ & NIV alone & $\begin{array}{l}\text { Time } \\
\text { cessation of } \\
\text { NIV }(\geq 6 \text { hours } \\
\text { without NIV) }\end{array}$ & Recruiting \\
\hline $\begin{array}{lr}\text { Weaning } & \text { Form } \\
\text { Mechanical } & \text { Ventilation } \\
\text { Using } \quad \text { Extracorporeal } \\
\mathrm{CO}_{2} & \text { Removal } \\
(\text { WeanPRO) } & \end{array}$ & NCT02259335 & $\begin{array}{l}\text { Mechanically ventilated } \\
\text { adults who meet readiness } \\
\text { criteria for weaning and fail } \\
\text { a T-piece trial after } 1 \text { hour } \\
\text { or before for a rise in } \\
\mathrm{PaCO}_{2}>20 \% \text { from baseline } \\
\text { and with } \mathrm{f} / \mathrm{Vt} \text { ratio }>100\end{array}$ & $\begin{array}{l}\text { Pilot study: } \\
15\end{array}$ & $\begin{array}{l}\text { VV-ECCO }{ }_{2} \mathrm{R} \\
\text { during the T- } \\
\text { piece trial }\end{array}$ & Nil & $\begin{array}{l}\text { Passing a } \\
\text { weaning trial } \\
\text { using a T-piece } \\
\text { method, and } \\
\text { avoiding } \\
\text { reintubation } \\
\text { within } 48-\text { hours } \\
\text { of } \mathrm{ECCO}_{2} \mathrm{R} \\
\text { device removal }\end{array}$ & Recruiting \\
\hline $\begin{array}{l}\text { Extracorporeal } \mathrm{CO}_{2} \\
\text { Removal With the } \\
\text { Hemolung RAS for } \\
\text { Mechanical Ventilation } \\
\text { Avoidance During } \\
\text { Acute Exacerbation of } \\
\text { COPD (VENT-AVOID) }\end{array}$ & NCT03255057 & $\begin{array}{l}\text { Adults with acute } \\
\text { exacerbation of COPD and } \\
\text { hypercapnic respiratory } \\
\text { failure with }<4 \text { days of non- } \\
\text { invasive ventilation or } \\
\text { invasive ventilation for }<4 \\
\text { days }\end{array}$ & $\begin{array}{l}300-800 \\
\text { (adaptive } \\
\text { design) }\end{array}$ & $\begin{array}{l}\text { VV-ECCO }{ }_{2} \mathrm{R} \\
\text { as an adjunct } \\
\text { or alternative } \\
\text { to standard-of- } \\
\text { care invasive } \\
\text { mechanical } \\
\text { ventilation }\end{array}$ & $\begin{array}{l}\text { Standard of } \\
\text { care non- } \\
\text { invasive or } \\
\text { invasive } \\
\text { mechanical } \\
\text { ventilation } \\
\text { alone }\end{array}$ & $\begin{array}{l}\text { Ventilator free } \\
\text { days at day } 60 \\
\text { from } \\
\text { randomisation }\end{array}$ & Recruiting \\
\hline
\end{tabular}

VV-ECCO 2 R: Veno-venous extracorporeal carbon dioxide removal; NIV: Non-invasive ventilation; COPD: Chronic obstructive pulmonary disease; $\mathrm{PaCO}_{2}$ : Partial pressure of arterial carbon dioxide; f/Vt: rapid shallow breathing index. 
Table 5: Complications associated with $\mathrm{ECCO}_{2} \mathrm{R}$

\begin{tabular}{|c|c|}
\hline \multirow{7}{*}{ Catheter insertion } & Catheter-site bleeding \\
\hline & Catheter-site infection \\
\hline & Inadvertent arterial insertion (in $\mathrm{VV}-\mathrm{ECCO}_{2} \mathrm{R}$ ) \\
\hline & Catheter dislodgement or kinking of tubing \\
\hline & Haematoma, aneurysm or pseudo-aneurysm formation \\
\hline & Compartment syndrome \\
\hline & Distal limb ischaemia (in AV-ECCO ${ }_{2} \mathrm{R}$ ) \\
\hline \multirow{7}{*}{ Therapy } & Worsening hypoxaemia during lower tidal volume ventilation \\
\hline & Bleeding (related to anticoagulation) \\
\hline & Haemolysis \\
\hline & Heparin-induced thrombocytopenia \\
\hline & Acquired coagulopathy (e.g. acquired von-Willebrand syndrome) \\
\hline & Air embolism \\
\hline & Recirculation \\
\hline \multirow{5}{*}{ Device failure } & Pump failure \\
\hline & Oxygenator failure \\
\hline & Heat exchanger malfunction \\
\hline & Clot formation \\
\hline & Air within circuit \\
\hline
\end{tabular}


Figure 1: Potential indications for $\mathrm{ECCO}_{2} \mathrm{R}$

$\mathrm{ECCO}_{2} \mathrm{R}$ is an emerging therapy that may have benefit in facilitating lower tidal volume ventilation, preventing intubation, facilitating extubation, and as a bridging therapy to lung transplant. 


\section{References}

1 Fitzgerald M, Millar J, Blackwood B, et al. Extracorporeal carbon dioxide removal for patients with acute respiratory failure secondary to the acute respiratory distress syndrome: a systematic review. Crit Care 2014; 18: 222.

2 Sklar MC, Beloncle F, Katsios CM, Brochard L, Friedrich JO. Extracorporeal carbon dioxide removal in patients with chronic obstructive pulmonary disease: a systematic review. Intensive Care Med 2015; 41: 1752-62.

3 Morelli A, Del Sorbo L, Pesenti A, Ranieri VM, Fan E. Extracorporeal carbon dioxide removal (ECCO2R) in patients with acute respiratory failure. Intensive Care Med 2017; 43: 519-30.

4 Gattinoni L, Agostoni A, Pesenti A, et al. Treatment of acute respiratory failure with lowfrequency positive-pressure ventilation and extracorporeal removal of CO2. Lancet 1980; 2: 292-4.

5 Zapol WM, Snider MT, Hill JD, et al. Extracorporeal membrane oxygenation in severe acute respiratory failure. A randomized prospective study. JAMA 1979; 242: 2193-6.

6 Boussarsar M, Thierry G, Jaber S, Roudot-Thoraval F, Lemaire F, Brochard L. Relationship between ventilatory settings and barotrauma in the acute respiratory distress syndrome. Intensive Care Med 2002; 28: 406-13.

7 Morris AH, Wallace CJ, Menlove RL, et al. Randomized clinical trial of pressure-controlled inverse ratio ventilation and extracorporeal $\mathrm{CO} 2$ removal for adult respiratory distress syndrome. Am J Respir Crit Care Med 1994; 149: 295-305.

8 Slutsky AS, Ranieri VM. Ventilator-Induced Lung Injury. N Engl J Med 2013; 369: 212636.

9 The Acute Respiratory Distress Syndrome Network. Ventilation with Lower Tidal Volumes as Compared with Traditional Tidal Volumes for Acute Lung Injury and the Acute Respiratory Distress Syndrome. N Engl J Med 2000; 342: 1301-8.

10Terragni PP, Del Sorbo L, Mascia L, et al. Tidal Volume Lower than $6 \mathrm{ml} / \mathrm{kg}$ Enhances Lung Protection: Role of Extracorporeal Carbon Dioxide Removal. Anesthesiology 2009; 111: 826-35.

11Terragni $\mathrm{P}$, Maiolo $\mathrm{G}$, Ranieri VM. Role and potentials of low-flow $\mathrm{CO}(2)$ removal system in mechanical ventilation. Curr Opin Crit Care 2012; 18: 93-8.

12Pesenti A, Patroniti N, Fumagalli R. Carbon dioxide dialysis will save the lung. Crit Care Med 2010; 38: S549-54.

13Camporota L, Barrett N. Current Applications for the Use of Extracorporeal Carbon Dioxide Removal in Critically III Patients. BioMed Res Int 2016; 2016: e9781695.

14Cove ME, MacLaren G, Federspiel WJ, Kellum JA. Bench to bedside review: Extracorporeal carbon dioxide removal, past present and future. Crit Care 2012; 16: 232.

15Fan E, Del Sorbo L, Goligher EC, et al. An Official American Thoracic Society/European Society of Intensive Care Medicine/Society of Critical Care Medicine Clinical Practice Guideline: Mechanical Ventilation in Adult Patients with Acute Respiratory Distress Syndrome. Am J Respir Crit Care Med 2017; 195: 1253-63. 
16 Grasso S, Stripoli T, Mazzone P, et al. Low Respiratory Rate Plus Minimally Invasive Extracorporeal Co2 Removal Decreases Systemic and Pulmonary Inflammatory Mediators in Experimental Acute Respiratory Distress Syndrome*: Crit Care Med 2014; 42: e451-60.

17Bellani G, Laffey JG, Pham T, et al. Epidemiology, patterns of care, and mortality for patients with acute respiratory distress syndrome in intensive care units in 50 countries. JAMA 2016; 315: 788-800.

18Curley G, Laffey JG, Kavanagh BP. Bench-to-bedside review: Carbon dioxide. Crit Care 2010; 14: 220.

19Masterson C, Otulakowski G, Kavanagh BP. Hypercapnia: clinical relevance and mechanisms of action. Curr Opin Crit Care 2015; 21: 7-12.

20 Nin N, Muriel A, Peñuelas O, et al. Severe hypercapnia and outcome of mechanically ventilated patients with moderate or severe acute respiratory distress syndrome. Intensive Care Med 2017; 43: 200-8.

21Del Sorbo L, Pisani L, Filippini C, et al. Extracorporeal Co2 Removal in Hypercapnic Patients At Risk of Noninvasive Ventilation Failure: A Matched Cohort Study With Historical Control*. Crit Care Med 2015; 43: 120-7.

22Braune S, Sieweke A, Brettner F, et al. The feasibility and safety of extracorporeal carbon dioxide removal to avoid intubation in patients with COPD unresponsive to noninvasive ventilation for acute hypercapnic respiratory failure (ECLAIR study): multicentre casecontrol study. Intensive Care Med 2016; 42: 1437-44.

23Abrams DC, Brenner K, Burkart KM, et al. Pilot study of extracorporeal carbon dioxide removal to facilitate extubation and ambulation in exacerbations of chronic obstructive pulmonary disease. Ann Am Thorac Soc 2013; 10: 307-14.

24Kluge S, Braune SA, Engel M, et al. Avoiding invasive mechanical ventilation by extracorporeal carbon dioxide removal in patients failing noninvasive ventilation. Intensive Care Med 2012; 38: 1632-9.

25Chacko J. Renal replacement therapy in the intensive care unit. Indian J Crit Care Med 2008; 12: 174-80.

26Karakitsos D, Labropoulos N, De Groot E, et al. Real-time ultrasound-guided catheterisation of the internal jugular vein: a prospective comparison with the landmark technique in critical care patients. Crit Care 2006; 10: R162.

27Fragou M, Gravvanis A, Dimitriou V, et al. Real-time ultrasound-guided subclavian vein cannulation versus the landmark method in critical care patients: A prospective randomized study*. Crit Care Med 2011; 39: 1607-12.

28Parienti J-J, Mégarbane B, Fischer M-O, et al. Catheter dysfunction and dialysis performance according to vascular access among 736 critically ill adults requiring renal replacement therapy: A randomized controlled study: Crit Care Med 2010; 38: 1118-25.

29Abrams D, Bacchetta M, Brodie D. Recirculation in Venovenous Extracorporeal Membrane Oxygenation. ASAIO J 2015; 61: 115. 
30Scaravilli V, Kreyer S, Linden K, et al. Enhanced Extracorporeal CO2 Removal by Regional Blood Acidification: Effect of Infusion of Three Metabolizable Acids. ASAIO J Am Soc Artif Intern Organs 1992 2015; 61: 533-9.

31 Cardenas VJ, Miller L, Lynch JE, Anderson MJ, Zwischenberger JB. Percutaneous venovenous $\mathrm{CO} 2$ removal with regional anticoagulation in an ovine model. ASAIO J Am Soc Artif Intern Organs 1992 2006; 52: 467-70.

32Allardet-Servent J, Castanier M, Signouret T, Soundaravelou R, Lepidi A, Seghboyan JM. Safety and Efficacy of Combined Extracorporeal CO2 Removal and Renal Replacement Therapy in Patients With Acute Respiratory Distress Syndrome and Acute Kidney Injury: The Pulmonary and Renal Support in Acute Respiratory Distress Syndrome Study. Crit Care Med 2015; 43: 2570-81.

33Forster C, Schriewer J, John S, Eckardt K-U, Willam C. Low-flow CO2removal integrated into a renal-replacement circuit can reduce acidosis and decrease vasopressor requirements. Crit Care 2013; 17: R154.

34Schmidt M, Jaber S, Zogheib E, Godet T, Capellier G, Combes A. Feasibility and safety of low-flow extracorporeal $\mathrm{CO} 2$ removal managed with a renal replacement platform to enhance lung-protective ventilation of patients with mild-to-moderate ARDS. Crit Care 2018; 22: 122.

35Zanella A, Mangili P, Redaelli S, et al. Regional Blood Acidification Enhances Extracorporeal Carbon Dioxide Removal: A 48-hour Animal Study. Anesthesiology 2014; 120: 416-24.

36Zanella A, Mangili P, Giani M, et al. Extracorporeal carbon dioxide removal through ventilation of acidified dialysate: An experimental study. $J$ Heart Lung Transplant 2014; 33: $536-41$.

37Zanella A, Castagna L, Salerno D, et al. Respiratory Electrodialysis. A Novel, Highly Efficient Extracorporeal CO2 Removal Technique. Am J Respir Crit Care Med 2015; 192: 719-26.

38Arazawa DT, Kimmel JD, Finn MC, Federspiel WJ. Acidic sweep gas with carbonic anhydrase coated hollow fiber membranes synergistically accelerates $\mathrm{CO} 2$ removal from blood. Acta Biomater 2015; 25: 143-9.

39Arazawa DT, Oh H-I, Ye S-H, et al. Immobilized carbonic anhydrase on hollow fiber membranes accelerates CO2 removal from blood. J Membr Sci 2012; 403-404: 25-31.

40Briel M, Meade M, Mercat A, et al. Higher vs lower positive end-expiratory pressure in patients with acute lung injury and acute respiratory distress syndrome: Systematic review and meta-analysis. JAMA 2010; 303: 865-73.

41 Neto A S, Cardoso S, Manetta J, et al. Association between use of lung-protective ventilation with lower tidal volumes and clinical outcomes among patients without acute respiratory distress syndrome: A meta-analysis. JAMA 2012; 308: 1651-9.

42Terragni PP, Rosboch G, Tealdi A, et al. Tidal Hyperinflation during Low Tidal Volume Ventilation in Acute Respiratory Distress Syndrome. Am J Respir Crit Care Med 2007; 175: 160-6. 
43Bein T, Weber-Carstens $S$, Goldmann A, et al. Lower tidal volume strategy $(\approx 3 \mathrm{ml} / \mathrm{kg})$ combined with extracorporeal $\mathrm{CO} 2$ removal versus 'conventional' protective ventilation (6 $\mathrm{ml} / \mathrm{kg}$ ) in severe ARDS. Intensive Care Med 2013; 39: 847-56.

44McNamee JJ, Gillies MA, Barrett NA, et al. pRotective vEntilation with veno-venouS lung assis T in respiratory failure: A protocol for a multicentre randomised controlled trial of extracorporeal carbon dioxide removal in patients with acute hypoxaemic respiratory failure. J Intensive Care Soc 2017; 18: 159-69.

45National Institute for Health and Care Excellence. Extracorporeal carbon dioxide removal for acute respiratory failure. 2016; published online Aug 24.

https://www.nice.org.uk/guidance/ipg564/chapter/1-recommendations (accessed Feb 13, 2017).

46Richard C, Argaud L, Blet A, et al. Assistance extracorporelle au cours du syndrome de détresse respiratoire aiguë (chez l'adulte et l'enfant, à l'exclusion du nouveau-né). Conférence de consensus organisée par la Société de réanimation de langue française. Réanimation 2013; 22: 548-66.

47Hoo GW, Hakimian N, Santiago SM. Hypercapnic respiratory failure in COPD patients: response to therapy. Chest 2000; 117: 169-77.

48Chandra D, Stamm JA, Taylor B, et al. Outcomes of noninvasive ventilation for acute exacerbations of chronic obstructive pulmonary disease in the United States, 1998-2008. Am J Respir Crit Care Med 2012; 185: 152-9.

49Braune $\mathrm{S}$, Burchardi $\mathrm{H}$, Engel $\mathrm{M}$, et al. The use of extracorporeal carbon dioxide removal to avoid intubation in patients failing non-invasive ventilation--a cost analysis. BMC Anesthesiol 2015; 15: 160.

50Diehl J-L, Piquilloud L, Richard J-CM, Mancebo J, Mercat A. Effects of extracorporeal carbon dioxide removal on work of breathing in patients with chronic obstructive pulmonary disease. Intensive Care Med 2016; 42: 951-2.

51Burki NK, Mani RK, Herth FJF, et al. A novel extracorporeal CO(2) removal system: results of a pilot study of hypercapnic respiratory failure in patients with COPD. Chest 2013; 143: 678-86.

52Elliot SC, Paramasivam K, Oram J, Bodenham AR, Howell SJ, Mallick A. Pumpless extracorporeal carbon dioxide removal for life-threatening asthma. Crit Care Med 2007; 35: 945-8.

53Tajimi K, Kasai T, Nakatani T, Kobayashi K. Extracorporeal lung assist for patient with hypercapnia due to status asthmaticus. Intensive Care Med 1988; 14: 588-9.

54 Sakai M, Ohteki H, Doi K, Narita Y. Clinical use of extracorporeal lung assist for a patient in status asthmaticus. Ann Thorac Surg 1996; 62: 885-7.

55Brenner K, Abrams DC, Agerstrand CL, Brodie D. Extracorporeal carbon dioxide removal for refractory status asthmaticus: experience in distinct exacerbation phenotypes. Perfusion 2014; 29: 26-8.

56Schellongowski $\mathrm{P}$, Riss K, Staudinger T, et al. Extracorporeal CO2 removal as bridge to lung transplantation in life-threatening hypercapnia. Transpl Int 2015; 28: 297-304. 
57Biscotti M, Gannon WD, Agerstrand C, et al. Awake Extracorporeal Membrane Oxygenation as Bridge to Lung Transplantation: A 9-Year Experience. Ann Thorac Surg 2017; 104: 412-9.

58Parienti J-J, Mongardon N, Mégarbane B, et al. Intravascular Complications of Central Venous Catheterization by Insertion Site. N Engl J Med 2015; 373: 1220-9.

59Combes A, Hajage D, Capellier G, et al. Extracorporeal Membrane Oxygenation for Severe Acute Respiratory Distress Syndrome. N Engl J Med 2018; 378: 1965-75.

60Lockie CJA, Gillon SA, Barrett NA, et al. Severe respiratory failure, extracorporeal membrane oxygenation, and intracranial hemorrhage. Crit Care Med 2017; 45: 1642-9.

61Peperstraete H, Eloot S, Depuydt P, De Somer F, Roosens C, Hoste E. Low flow extracorporeal $\mathrm{CO} 2$ removal in ARDS patients: a prospective short-term crossover pilot study. BMC Anesthesiol 2017; 17: 155.

62Kalbhenn J, Neuffer N, Zieger B, Schmutz A. Is Extracorporeal CO2 Removal Really 'Safe' and 'Less' Invasive? Observation of Blood Injury and Coagulation Impairment during ECCO2R. ASAIO J 2017; 63: 666-71.

63Qian Q, Nath KA, Wu Y, Daoud TM, Sethi S. Hemolysis and Acute Kidney Failure. Am J Kidney Dis 2010; 56: 780-4.

64Combes A, Brodie D, Bartlett R, et al. Position paper for the organization of extracorporeal membrane oxygenation programs for acute respiratory failure in adult patients. Am J Respir Crit Care Med 2014; 190: 488-96.

65Noah MA, Peek GJ, Finney SJ, et al. Referral to an Extracorporeal Membrane Oxygenation Center and Mortality Among Patients With Severe 2009 Influenza A(H1N1). JAMA 2011; 306: 1659-68.

66Peek GJ, Mugford M, Tiruvoipati R, et al. Efficacy and economic assessment of conventional ventilatory support versus extracorporeal membrane oxygenation for severe adult respiratory failure (CESAR): a multicentre randomised controlled trial. Lancet 2009; 374: 1351-63.

67Kahn JM, Goss CH, Heagerty PJ, Kramer AA, O'Brien CR, Rubenfeld GD. Hospital volume and the outcomes of mechanical ventilation. N Engl J Med 2006; 355: 41-50. 


\section{List of abbreviations}

$\mathrm{ECCO}_{2} \mathrm{R}$ : Extracorporeal carbon dioxide removal

ARDS: Acute respiratory distress syndrome

ECMO: Extracorporeal membrane oxygenation

VV: Veno-venous

AV: Arterio-venous

aPTT: activated partial thromboplastin time

PBW: Predicted body weight

$\mathrm{PaO} 2 / \mathrm{FiO} 2$ ratio: Ratio of partial pressure of arterial blood oxygen content to inspired fraction of oxygen

COPD: Chronic obstructive pulmonary disease

AKI: Acute kidney injury

\section{Contributing authors}

Dr Darryl Abrams

Professor Alain Combes

Dr Eddy Fan

Professor John Fraser

Dr Carol Hodgson

Dr Nicolò Patroniti

Professor Antonio Pesenti

Dr Rob Mac Sweeney

Dr Jordi Mancebo Cortes

Dr Thomas Mueller

Dr Tài Pham

Professor Marco Ranieri

Dr Matthieu Schmidt

Dr Kiran Shekar

\section{Author contributions}

AJB and MS wrote the 1st draft of the manuscript. JJM, DB, ASS, LB and DFM reviewed and edited the manuscript. All contributing authors provided edits to the manuscript. All authors approve the final version. We confirm that no medical writers were used to write this review. 


\section{Acknowledgements}

We thank Adrian Knipe (Belfast Health and Social Care Trust) for drawing the figures.

\section{Funding source}

There was no funding for this work.

\section{Conflict of interest}

Drs. Boyle, McNamee and McAuley report grants from Northern Ireland Health and Social Care Research and Development Agency and NIHR HTA, with in-kind support from ALung Technologies, Inc, for a clinical trial of ECCO2R. ALung Technologies, Inc, have no role in the study design or conduct. Dr. Sklar has nothing to disclose. Dr. Brodie is currently the cochair of the Trial Steering Committee for the VENT-AVOID trial sponsored by ALung Technologies, he was previously on the medical advisory board of ALung Technologies and Kadence. All compensation for these activities is paid to Columbia University. Dr. Slutsky reports personal fees from Baxter, personal fees from Maquet Critical Care, personal fees from Novalung/Xenios, during the conduct of the study; personal fees from Bayer, personal fees from Faron, personal fees from Ferring, outside the submitted work. Dr. Brochard reports grants from Medtronic Covidien, non-financial support from General Electric, nonfinancial support from Philips, non-financial support from Air Liquide, grants and nonfinancial support from Fisher Paykel, outside the submitted work. Outside the submitted work, Dr McAuley reports personal fees from consultancy for Peptinnovate, Bayer, GlaxoSmithKline, Boehringer Ingelheim. Dr McAuley has also received grants from NIHR and other funders as an investigator for clinical trials in ARDS. Dr McAuley's institution has received funding from GlaxoSmithKline for Dr McAuley undertaking bronchoscopy as part of a clinical trial. In addition, Dr McAuley has a patent US8962032 for a novel treatment for ARDS issued to his institution. 